\title{
Brazil After Lula and Dilma Administrations: The Bolsa Família and Implantation of a Basic Income
}

\author{
Maria Ozanira da Silva e Silva ${ }^{a}$, Valéria Ferreira Santos de Almada Limaa
}

\begin{abstract}
The Family Stipend Program (Bolsa Família-BF) has been implemented since 2003 as the main strategy to face poverty in Brazil. Its benefit is the transfer of income to poor and extremely poor families as well as to articulate the monetary income transfer with some structural policies, mainly education, health, and work. The BF has already reached almost 14 million of families and is implemented in all the 5,545 Brazilian municipalities, i.e. about $1 / 4$ of the Brazilian population. The program requires the fulfillment of some conditionalities in the field of education and health, such as: enrollment and attendance of the children and adolescents in school; children must get basic health care; and pregnant women must receive prenatal care. The BF is considered in Brazil, according to Eduardo Suplicy's Law Bill 266/2001 sanctioned by President Lula on January 8 of 2004, as the first step towards creating a Citizenship Basic Income. The goal of this proposal is to present and to problematize the recent political and economic post Lula and Dilma Administrations situation in order to demonstrate the climate of regression in the social protection programs and the dismantling of the same social rights already conquered by the worker class and the poor population. Among the programs to be mentioned is the BF. The intention is to highlight the economic situation of a long recession and rise in unemployment rates besides the decrease of the workers' income and the repression of social movements, in order to develop an analysis of the BF in this context.
\end{abstract}

\section{Keywords}

Family stipend, income transfer programs, Brazil

The Family Stipend Program (Bolsa Familia-BF) is the largest income transfer program implemented in Latin America. It is part of the Brazilian Social Protection System and the main program dealing with extreme poverty in a country with a surface area of $8,547,403 \mathrm{~km}^{2}$, divided into five regions, with 26 states and 5,570 municipalities, and the Federal District, Brasília. Projections by the Brazilian Institute of Geography and Statistics (Instituto Brasileiro de Geografia e Estatística-IBGE) indicate a population of 207,537,853 inhabitants in May 2017. According to censuses, the Brazilian fertility index has been decreasing, reaching 1.86 children per family in 2010 . In the same year, the number of private domiciles was 67.6 million, with an average of 3.3 residents per domicile. There is a marked tendency for the age structure of the population to converge towards aging, with a recorded participation of the population 60

\footnotetext{
aFederal University of Maranhão State, Brazil

\section{Correspondent Author:}

Maria Ozanira da Silva e Silva, Av. dos Holandeses, 2000, Condomínio The Prime, Casa ETA 03, Calhau, São Luís, MA, Brasil, CEP: 65071380
} 
years old or over as $11.3 \%$ in 2010 (Instituto Brasileiro de Geografia e Estatística [IBGE] 2011).

The development of the Brazilian Social Protection System started in 1930. That year, a profound economic and social transformation began, with the transition from an agricultural exporting development model to a model of urban-industrial development. In this context, the Brazilian social structure began to include a new working class, urban workers. Due to the dynamics of this situation, new demands emerged to satisfy collective needs, as a consequence of the emerging industrial process, and with it, the increased relocation of the rural population to the city, generating a growing urbanization process, accompanied by its consequences and demands.

Brazilian economic development was intensified from 1970 onwards, in the context of a Military Dictatorship established in 1964, when the development of capitalism in Brazil took on a monopolistic perspective, with internationalization and centralization, requiring from the State that it supported the infrastructure required by the new demands of capital. In this authoritarian and centralizing context, social protection advanced adopting social programs that ultimately functioned as a palliative to reduce the strong repression of the popular sectors and the working class, maintaining its function of reproducing the work force and seeking legitimation of the authoritarian regime.

In the 1980s, there already was a significant organized movement of dissatisfaction with the military regime. Strong demands were presented by the social struggles, claiming the expansion of social rights and resolution of the social debt, especially as results of the wage squeeze and the increasing concentration of income. The struggles were manifested both in the field of production and consumption, with the emergence of what began to be called new trade unionism and new social movements.

The dynamics of political reality in the 1980s culminated with the Federal Constitution of 1988 which expanded social rights and established social security, consisting of the policies for health, social assistance, and social security, significantly expanding the System of Social Protection in Brazil, by extending the rights even to the Brazilians who were not in the formal labor market.

In this context with the expansion of rights and social protection, a debate began about income transfer programs whose first experiences were implemented in 1995, initially at a municipal level, followed by experiences adopted by several states, reaching a significant expansion from 2001 onwards by expanding national programs, culminating in the creation of the $\mathrm{BF}$ in 2003. From then, the income transfer programs became central to the Brazilian Social Protection System (Silva, Yazbek, and Giovanni 2014).

In this text, the BF is located at the current economic and political juncture from 2016 onwards, when what the authors consider the dismantling of social rights achieved by Brazilian workers began to occur, with a significant regression of the social protection aimed at the segments of the population that live in a situation of poverty and extreme poverty. For this, the authors present a problematizing discussion about the current economic and political situation in Brazil, after the Lula and Dilma Administrations (2003-2016), continuing with the presentation of a general characterization of the $\mathrm{BF}$ and then highlighting possible pushbacks of the juncture presented in its configuration, development, and perspectives. Thus, the authors attempt to size possible repercussions of the implementation of a Citizenship Basic Income directed at all Brazilians and foreigners who have lived in Brazil for five years or more, as determined by Law 10.835 of January 8, 2004, introduced by then Senator Eduardo Suplicy of the Workers' Party (Partido dos Trabalhadores-PT) and sanctioned by President Luís Inácio Lula da Silva on January 8, 2004. This is because the BF is indicated as a first step in the process to implement the Citizenship Basic Income in Brazil, and the initial 
criterion to implement it is the inclusion of all who live in a state of poverty and extreme poverty, who are the target public of the BF.

\section{ECONOMIC AND POLITICAL JUNCTURE IN BRAZIL AFTER THE LULA AND DILMA ADMINISTRATIONS}

At the beginning of twenty-first century, as in most of the countries of Latin America where progressive administrations came to power originating in the left wing parties, Brazil, under the presidency of Luís Inácio Lula da Silva of the PT, underwent a major inflection in its economic and social scene, leading some scholars to glimpse a break with the development pattern that had occurred until then, towards a so-called "Neodevelopmentalism". This inflection was expressed by the association between the renewal of economic growth, furthered by a favorable international context, and the improvement of social indicators, above all those related to the labor market, poverty, and inequality.

Indeed, following the context of a marked destructuring of the labor market in the 1990s, with negative effects on poverty and inequality, the Gross Domestic Product (GDP-Produto Interno Bruto-PIB) began to grow more vigorously, and reached a rate of $5.4 \%$ in 2007. According to Lima, Nascimento, and Mochel (2009), based on data from the Annual Report on Social Information (Relação Anual de Informações Sociais-RAIS) of the Ministry of Labor and Employment (Ministério do Trabalho e Emprego-MTE), this generated 11.010 million formal jobs during the period from January 2003 to September 2008. Consequently, according to Ramos and Cavaleri (2009), the level of total employment caused a drop in the degree of informality which, in 2007, reached the lowest level of the decade, 50.9\%.

As regards the extreme poverty and poverty rates, according to the Institute of Applied Economic Research (Instituto de Pesquisa Econômica Aplicada
[IPEA] 2010), between 1995 and 2008, 12.5 million people moved out of a situation of extreme poverty (per capita average domicile income of up to a quarter of the monthly minimum wage), reducing the percentage of people living under these conditions to almost half (from $20.9 \%$ to $10.5 \%$ ). At the same time, the rate of absolute poverty (per capita average domicile income of up to half of the monthly minimum wage) went down by $43.4 \%$, in 1995 , to $28.8 \%$, in 2008. Besides the reduction of extreme poverty and absolute poverty, according to Barros et al. (2009), between 2001 and 2007, the Gini coefficient, one of the most traditional measures of inequality, fell seven percentage points; although despite this, Brazil continued to occupy one of the worst positions in the ranking of most unequal countries in the world.

In the second decade of the twenty-first century, already under the Dilma Roussef Administration, which was also of the PT, and faced with an international worsening of the capitalist crisis, a new inflection in the Brazilian economy was identified, with negative effects on the labor market. In fact, according to Holanda and Anchieta Junior (2014), based on data from the General Registry of Employed and Unemployed (Cadastro Geral de Empregados e Desempregados-CAGED), while in 2010, in a context of GDP growth on the order of $7.5 \%, 3.1$ million formal jobs were generated in the country; in 2013, this number dropped to 1.1 million, which was less than that in 2009, the year when the international financial crisis occurred. On the other hand and paradoxically, according to the Monthly Survey of Jobs (Pesquisa Mensal de Emprego-PME) disseminated by IBGE, the rate of unemployment in 2013 reached the lowest level of the series begun in 2002 , corresponding to $4.3 \%$, approaching a situation of full employment.

However, since early 2015, during President Dilma Roussef's second term in office, Brazil has undergone a profound political and institutional crisis, 
worsened by the advance of Operation Car Wash (Operação Lava-Jato) $^{1}$, with a clear polarization of society around distinct political-ideological projects and a marked advance of conservatism. This crisis is further intensified by a situation of accelerated deterioration of macroeconomic conditions and fiscal adjustment which, according to data from CAGED, led to closing down 137 thousand formal jobs in the first four months of the year. Considering the last 12 months that ended in April 2015, the result was even worse with 263 thousand jobs being closed down (Lima, Anchieta Junior, and Sousa 2015).

Particularly as regards the macroeconomic conditions, indeed, the cycle of the rise in the rate of interest of the Special System for Liquidation and Custody (Sistema Especial de Liquidação e de Custódia-SELIC) which began in 2014, the readjustment of managed prices (electricity and fuels) consequently speeding up the inflation during the first quarter of 2015, added to the effects of the already mentioned Operation Car Wash, negatively affected the performance of the GDP with negative repercussions on the job market.

In this context, despite the already mentioned resiliency of the rate of unemployment at historically low levels against a recessive scenario, this, according to the PME, reached the mean of $6.0 \%$ in the six main Brazilian metropolitan regions in the first four months of 2015 , against $5.0 \%$ in the same four-month period of 2014 (IBGE 2015a).

According to National Household Sample Survey (Pesquisa Nacional por Amostra de Domicílios Continua-PNAD Continua) (IBGE 2015b), whose coverage is greater than that of the PME, the number of unemployed increased by almost 1.5 million people passing from the last quarter of 2014 to the first one of 2015 , raising the unemployment rate from $6.5 \%$ to 7.9\% during the same period (Lima et al. 2015). Also, according to PNAD Continua, the mean rate of unemployment in Brazil in 2015 was $8.5 \%$ (IBGE 2015b).
In 2016, the worsening of the political-institutional crisis culminated in the approval of President Dilma Rousseff's impeachment, and the government was taken over by Vice-President of Brazil Michel Temer who belongs to the Brazilian Democratic Movement Party (Partido do Movimento Democrático Brasileiro-PMDB). This meant the victory of a conservative project that jeopardizes major advances of the country, especially in the social sphere, during the first decade of 2000 . This is because precisely these advances were considered to be the main causes of the worsening of the public deficit, the acceleration of inflation, and the significant drop in the GDP growth rate which diminished from $2.7 \%$ to $0.1 \%$ between 2013 and 2014, reaching the negative indices of $3.8 \%$ in 2015 and $3.5 \%$ in 2016 (IBGE 2015b; Instituto Maranhense de Estudos Socioeconômicos e Cartográficos [IMESC] 2017).

This said, according to the official version, the solution to the economic crisis would necessarily require furthering the fiscal adjustment that already began in President Dilma Rousseff's second term, by strict cutbacks of funds, especially in the social area, and the approval of reforms in the labor and social security areas, which is extremely regressive from the point of view of the working classes. This adjustment, however, did not question the misuse of funds with payments of interest on the public debt, which, according to Pochmann $(2017)^{2}$, reached about $8.5 \%$ of the GDP in 2015 , compared to $5.7 \%$ in 2014 , besides the waste of subsidies and exemptions for privileged sectors. Furthermore, it did not even come close to the need for the reform of the Brazilian tax system which is extremely regressive, whose burden of taxes, rates, and contributions ultimately favors the rich to the detriment of the poor.

To counter this context of sharpening the political institutional crisis, with tax adjustment and deterioration of the macroeconomic conditions in the labor market indicators, there is a significant elevation of the mean rate of unemployment which, according 
to PNAD Contínua (IBGE 2016), reached $11.5 \%$, in 2016 against the previously mentioned index of $8.5 \%$ in 2015 (Lima, Moraes, and Silva 2017).

As regards formal employment, according to the data of the CAGED, the balance of jobs in the country (1.3 million net dismissals) was negative, marking the second year of retraction of the formal labor market so that between 2015 and 2016, there were 22 months in which there were more dismissals than admittances (Lima et al. 2017).

The marked worsening observed in the formal labor market also showed a deterioration in the quality of jobs. In fact, according to data from PNAD Contínua (IBGE 2016), successive drops were observed in the formal jobs obeying the employment legislation (Consolidation of Labor Laws-Consolidação das Leis do Trabalho-CLT) which accounted for $41.4 \%$ of the employed workers in Brazil in 2014, falling to $40.6 \%$ in 2015 and to $39.8 \%$ in 2016 . On the other hand, the percentage of workers employed without a signed employment card jumped from 15.7\% in 2014 to $16.3 \%$ in 2016 . Likewise, there was an elevation of the percentage of self-employed workers, most of whom do not have rights according to labor laws and social security, and this percentage went from $23.4 \%$ in 2014 to $24.5 \%$ in 2016 (Lima et al. 2017).

From the standpoint of rates of poverty and extreme poverty, although according to IPEA (2016), these have dropped significantly between 2004 and 2014 , from a level of $20.0 \%$ to $6.0 \%$ and from $7.0 \%$ to $2.0 \%$, respectively, this descending trajectory is threatened by the reversion of the economic scenario in 2014, accompanied by the political crisis that began in 2015. The same is applied to inequality, measured by the Gini coefficient which fell 9.7 percentage points during the same period, a tendency that is likewise threatened not only by the directions taken by the economy, but also by the doubts and uncertainties that currently are imposed on the institutionality of the social protection system and on the regulatory framework of work.
Indeed, within the strict fiscal adjustment implemented by the Temer Administration, the Proposal for Amendment to the Constitution no. 55 of 2016, called Proposed Constitutional Amendment (Proposta de Emenda Constitucional-PEC) of the Cap to Public Expenditures was approved. It institutes the New Fiscal Regime within the sphere of the Fiscal and Federal Social Security Budgets, to remain in force for 20 financial years, establishing individualized limits ${ }^{3}$ for the primary expenditures of each of the three Powers, the Federal Prosecutor's Office, and the Attorney General's Office.

Furthermore, in this context of a crisis, with negative effects on the Brazilian labor market, there is a renewed debate regarding the need to flexibilize labor relations, culminating in the enactment of Law no. 13,429 of March 31, 2017 by the Federal Congress which was sanctioned by the President of the Republic. This broadens and further flexibilizes the possibilities of outsourcing and employment of temporary employees, which will certainly impose marked and regressive changes on the structure of the Brazilian labor market.

Two proposals for reform are about to be voted and approved in National Congress to complement the package of regressive measures. They are an attack on major rights that were conquered with great effort by the working class: the CLT and Social Security (Previdência Social).

Regarding the first, the premises that support it are considered false. According to them, the Brazilian labor market is very rigid, favored by "archaic" or "obsolete" laws that make the costs of employment contracts and dismissals of labor more expensive than that in other countries. This is because high turnover (of employees) indicates that the Brazilian labor market is already very flexible. Moreover, there is no proof of a correlation between flexibilizing the labor market and generating jobs, and this is corroborated by studies performed by the International Labor Organization (ILO) (Lima et al. 2017). 
As to reforming Social Security, according to Pochmann (2017), this proposes to subvert the current model of social security established by the Federal Constitution in 1988, which was to be funded, besides the direct contribution of workers and employers, by taxes (Contribution to Funding of Social Security-Contribuição para o Financiamento da Seguridade Social-COFINS, for instance), paid for by the entire society, with the coverage of costs of retirement and pensions taking place concomitantly with health and social assistance.

It is, therefore, in this grave economic and political-institutional context, with the advance of conservatism in public policies and attack on social rights that the authors will now discuss the BF.

\section{THE FAMILY STIPEND IN THE CURRENT BRAZILIAN JUNCTURE: CHALLENGES FOR THE CONSTRUCTION OF A CITIZENSHIP BASIC INCOME}

This item initially presents a characterization of the BF as the largest and broadest income transfer for poor and extremely poor families that is presently being implemented in Brazil. It continues to situate the BF in the current Brazilian juncture, highlighting the context of dismantling social rights and regression of social protection to the poor and the repercussion of this reality on the $\mathrm{BF}$, as an initial strategy to implement a Citizenship Basic Income in Brazil.

\section{The BF4: An Overview}

The $\mathrm{BF}$, a program which guarantees a minimum income $^{5}$, is the largest income transfer program implemented in Brazil. With other income transfer programs $^{6}$, it is central to the Social Protection System in the country.

The BF, according to its national managing agency, the Ministry of Social Development (Ministério do Desenvolvimento Social e Combate à Fome-MDS) proposes to help fight poverty and inequality in Brazil.
Established in October 2003, it comprises three main axes: a complement of income represented by monetary transfers to the beneficiary families; conditionalities, considered commitments to be made by the families to support access to the rights to health, education, and social assistance; and articulation with other programs and actions.

The insertion of the families in the BF occurs initially by enrollment in the Single Registry (Cadastro Único-CadÚnico) ${ }^{7}$, and later the families are selected by a computerized system based on the data they informed in the Single Registry and on the Program Rules, whose basic criterion is the classification of the family as poor, per capita family income of up to $\mathrm{R} \$ 170.00$ (U\$ 53.96) ${ }^{8}$, and extremely poor, per capita family income of up to R $\$ 85.00$ (U\$ 26.98). However, the concession of the benefit occurs under the condition of the number of families that have already been helped, as related to the estimation of families that are requesting it, considering a fixed quota for each municipality. Its limit is the program budget. Once the family has been selected, it receives a bank cash card called Family Stipend Card (Cartão Bolsa Família), issued by the Federal Savings Bank (Caixa Econômica Federal), sent through the post to the homes of the families selected.

The development of the BF has shown a broad geographic spread with a growing number of families served ${ }^{9}$. In 2003, the first year of its implementation, $3,500,000$ families were included. In 2006, it was already implemented in a decentralized manner, in all Brazilian municipalities and in the Federal District. In May 2009, there were already $11,611,680$ poor and extremely poor families served, and in March 2014, the total number of families served reached $14,053,368$ families, with a total amount of $\$ 2,112,724,614.00$ (U\$ 670,706,226.66) paid in benefits to the families in that month. In May 2017, the total number of families served was 13,313,779, receiving a mean amount, considering the different benefits, of R $\$ 180.49$ (U\$ 57.29). That same month, 
the total amount transferred to the families was $\mathrm{R} \$ 2,402,987,404.00$ (U\$ 762,853,114.12) (Relatórios de Informações Sociais 2016).

Regarding the benefits, the BF articulates two types: the monetary benefits, considered a complement of the families' income, and the non-monetary ones, resulting from the articulation with other actions. The former are direct monetary transfers, aimed at directly relieving the impoverishment of the beneficiary families. On the other hand, the non-monetary benefits, offer of actions and complementary programs, aim at overcoming the vulnerabilities of the families, emphasizing the offer of professional qualification programs, insertion into the labor market, and credit to stimulate entrepreneurialism, besides the insertion of members of the beneficiary families into other complementary actions and programs, especially those offered by the Social Assistance Policy. Mediating the benefits, there are the conditionalities considered by those who created the $\mathrm{BF}$ as a reinforcement to the access to basic social rights in health, education, and social assistance, so that the program proposes to articulate a compensatory dimension (the monetary transfer) with a structuring dimension that involves programs and actions turned to the thus called overcoming of situations of vulnerability experienced by poor and extremely poor families, which are the target public of the BF.

The amount of monetary benefits paid monthly to the families is calculated case by case according to the family income and the number of people in the family, so that the per capita family income is more than $\mathrm{R} \$ 85.00$ (U\$ 26.98), the value indicating the extreme poverty line. On the other hand, the types and amount of benefits attributed to each family take into account the number of persons, ages, presence of pregnant women, and beneficiary family income. Thus, there is the Basic Benefit paid only to extremely poor families, a monthly amount of R\$85.00 (U\$ 26.98), while the variable benefits are identified in Table 1.
Further benefits, also according to the same source, are:

(1) Variable benefit linked to adolescents, to the amount of R $\$ 46.00$ (U\$ 14.60) (up to two per family), paid to the families with a monthly per capita income of up to R $\$ 170.00$ (U\$ 53.96) and that have adolescent children aged 16 and 17 years, with a requirement of $75 \%$ school attendance.

(2) Benefít to overcome extreme poverty, paid to the families that continue to have a monthly per capita family income of less than R $\$ 85.00$ (U\$ 26.98), even after receiving the types of benefits to which they have a right. This aims at ensuring that the family will surpass this basic income per person (Beneficios 2015).

Considering access to the benefits mentioned, according to the criteria established by the program, the minimum monetary value of the BF transferred monthly to each beneficiary family is $\mathrm{R} \$ 39.00$ (U\$ 12.38) and the mean value per family in May 2017 was R $\$ 180.49$ (U\$ 57.29). No family served by the BF can have a per capita family income of less than R $\$ 85.00$ (U\$ 26.98), considering the amount that places the families above the extreme poverty line.

It should be considered that the MDS does not direct nor restrict the way that the money transfer received by the families is used, considering what it calls guarantee and stimulation of the citizen autonomy of each of the families.

Benefits are paid mainly through the Family Stipend Card, used exclusively to draw the program benefits, in which the Social Identification Number (Número de Identificação Social-NIS) is recorded, as well as the name of the person responsible for the family (Responsável Familiar-RF) ${ }^{10}$. For this, the beneficiaries used a simplified bank account called Easy Bank Account (Conta Caixa Fácil), regulated by the Central Bank of Brazil, with guaranteed access to banking services for the low income public.

Besides being low, with a diversity of values, the benefits do not have a defined system for readjustment, and therefore their values are reduced 
Table 1. Variable Benefits (Granted to up to Five Children and Adolescents per Family)

\begin{tabular}{|c|c|}
\hline $\begin{array}{l}\text { Variable benefit linked to a child or } \\
\text { adolescent aged } 0 \text { to } 15 \text { years } \\
\mathrm{R} \$ 39.00 \text { (U\$12.38) }\end{array}$ & $\begin{array}{l}\text { Paid to families with a monthly per capita income of up to } \mathrm{R} \$ 170.00 \text { (U\$ } \$ 53.96 \text { ) who } \\
\text { have children or adolescents aged } 0 \text { to } 15 \text { years. }\end{array}$ \\
\hline $\begin{array}{l}\text { Variable benefit linked to a } \\
\text { pregnant woman } \\
\mathrm{R} \$ 39.00(\mathrm{U} \$ 12.38)\end{array}$ & $\begin{array}{l}\text { Paid to the families with a monthly per capita income of up to R\$ } 170.00 \text { (U\$ } 53.96 \text { ) who } \\
\text { include pregnant women, as long as the information is identified by the health system } \\
\text { and inserted into the Family Stipend in Health System. It consists of } 9 \text { installments. }\end{array}$ \\
\hline $\begin{array}{l}\text { Variable benefit linked to } \\
\text { breastfeeding women } \\
\mathrm{R} \$ 39.00 \text { (U\$ 12.38) }\end{array}$ & $\begin{array}{l}\text { Paid to families with a monthly per capita income of up to R } \$ 170.00 \text { (U\$ } 53.96 \text { ) who } \\
\text { include children aged } 0 \text { to } 6 \text { months, to a total of } 6 \text { installments, and the child's } \\
\text { information must be included in the CadÚnico until the sixth month of life. }\end{array}$ \\
\hline
\end{tabular}

Note: Source: (Benefícios 2015).

according to inflation ${ }^{11}$. However, the monthly periodicity of the money transfers and the scheduling that ensures that they will be regularly paid should be considered significant, and enable families to program the use of the resources received confidently.

Considering the forms of payment of the benefits, it should be emphasized that:

The transformation of the beneficiaries into bank clients who have a magnetic card appears to transform them into citizens of contemporary society, considering the idea that becoming a client of a bank has an entire symbolism displayed by consumer society, appearing to transform the beneficiaries of these programs into equals. This, no matter how desirable and positive it may seem, also has an ideological character, revealing belonging and integration (Silva 2014a: 75, the authors' translation).

As already mentioned, the BF considers it relevant to carry out certain conditionalities in order to enable families to continue to be inserted into the program. In education, the people responsible must enroll children and adolescents aged 6 to 17 years in school and maintain a monthly school attendance of $85 \%$ for children and adolecents aged 6 to 15 years, and of $75 \%$ for young people aged 16 to 17 years. Regarding health, the person responsible for the children must take those below the age of seven years to have their vaccines as listed in the vaccination calendar by the health teams and to weigh, measure, and follow up their growth and development, and pregnant women should undergo antenatal examination and visits to the Health Unit.

Compliance with these conditionalties is followed by the three levels of government (federal, state, and municipal). Information about school attendance and fulfilling the health care agenda are recorded in specific information systems, and there is also individual monitoring of the families that do not comply with the conditionalities. Monitoring is justified to ensure the education and health services provided by the authorities; to identify situations of vulnerability of the families that find it difficult to access public services; and to refer the families that are not complying with the conditionality to the social assistance network, seeking to overcome the vulnerabilties and return them to compliance with the conditionalities.

Since the BF is a focused program and subject to conditionalities, the families that do not comply with the established commitments are subject to a punitive process that ranges from warning, blocked benefits, suspension of benefits, and may be dismissed from the program when they repeatedly disobey the conditionalities even after they undergo a follow up by social assistance in the municipality where the program is implemented.

The families are dismissed from the program for two reasons: when they are no longer in a situation of 
poverty or extreme poverty because their monthly income has become higher than R $\$ 185.00$ (U\$ 58.73) or for repeated non-compliance with the conditionalities. It is required that the families update the information in the Single Registry of the Federal Government every two years. However, there is a proviso called Permanence Rule that ensures that the families will remain in the program when their income rises to up to half of a minimum wage per capita, as long as they voluntarily update the information in the Single Registry. The families can also voluntarily ask to leave the program, and can be reinserted in a period of 36 months, through a mechanism called Guaranteed Return if they find themselves again in a situation in which they fit the criteria of entry to the program.

From what has been presented above, the BF is a program focusing on poor and extremely poor families, so that the concession of the minimum income requires complex verifications, follow ups, and checking up on the family. This situation is worsened because the great majority of these families when inserted into the labor market, work informally, with low and unstable incomes and no right to social protection. How can one check on the constant variations in the family income? How to ensure the support necessary to vulnerable families that do not comply with the conditionalities? Law 10.835/2004, enacted by National Congress in 2003 and sanctioned by President Lula on January 8, 2004, proposes the implementation of a Citizenship Basic Income, whose initial stage would be to take care of the poor population and the $\mathrm{BF}$ is considered the initial stage for the implementation of Basic Income in Brazil.

How feasible is this process?

What are the limits posed by the design of the proposal of the BF itself, from the political conservative ideas of society, to which are added the limits established in the Brazilian juncture with the dismantling of rights and regression of social protection in the country for possible advances of this process?
That is what the authors intend to problematize below.

\section{The Currentness of the BF in a Juncture in Which Social Rights Are Being Dismantled and Regression of Social Protection to the Poor}

Considering the $\mathrm{BF}$ in the current situation of Brazil after 2015, it is necessary to take into account the reality presented and problematized in item 2 of this text: socio-economic and political juncture marked by a coup d'etat that occurred in May 2016, with the impeachment of President Dilma Rousseff, replaced by her Vice-President Michel Temer.

In a context of further neoliberalism, a new configuration of State is inaugurated: conservative and authoritarian, profoundly subjected to the interests of international financial capitalism with real disregard for democratic principles that had ruled Brazilian society, whose main consequence is a broad backward step taken by social and labor rights, besides the deactivation and reduction of social programs that are relevant to the poor population.

People are living in a context of despoiling the national riches, and intensification of the overexploitation of the labor force, and priority is given to use the Public Fund to service the domestic debt and to support demands and projects that are of interest to capital.

This is a reality of a confrontation of corporate projects represented by a break in a conciliatory pact sustained by the PT Administrations of Lula and Dilma (2003-2016) who, although they did not break with a development model that favors capitalism, sought to maintain a pact with the masses. This pact allowed the insertion, although only at points, of the popular segments into the production and consumption system, by adopting policies to deal with poverty in the rural area and in the city, among which are the BF, created by Lula in 2003, and the Brazil without Extreme Poverty Plan (Brasil sem Miséria) in $2011^{12}$, created by Dilma. According to this pact, 
capital, mainly financial capital, wins, but also the workers win because of the rise in the opportunities to enter the formal labor market, with technical training and to enter universities, and obtain greater access to housing. There is a significant growth in public expenditures on income transfer programs and the creation of the Single Social Assistance System (Sistema Único de Assistência Social-SUAS), increasing the social programs directed towards combating extreme poverty. Even more significant were the rise in the real value of the minimum wage by more than $70 \%$, from 2003 to 2015 and the significant elevation in the income from work; refusal to dismantle the CLT; creation of the regulatory framework of the Pre-Salt (Pré Sal) ${ }^{13}$, giving funds to education and health, increasing policies of rights to the inclusion of historically discriminated segments, outstanding among which are the policies on racial equality; implementation of many programs in the rural area, enhancing the value of the rural worker who is responsible for the subsistence economy and for small production (Carvalho 2017).

In the international sphere, Brazilian protagonism in the Latin American region and in its relations with the emerging countries (Russia, India, China, and South Africa) that constitute the BRICS should be highlighted, with the significant leadership of Brazil, besides moving away from a policy of historical subordination to the United States.

Despite the positivity of the pact with the workers, and the undeniable advance of policies and social programs to deal with poverty, the PT Administrations did not bet on popular power and the capacity of social movements to mobilize as subjects of pressure on the Parliament to carry out essential reforms, such as political reform, the fiscal reform, and land reform. On the contrary, they chose to take up a policy of alliances with conservative parties and politicians (Carvalho 2017).

The pact with the PT Administrations, favored installing a contradiction: on the one hand, a proposal to broaden social rights, generate jobs and income, and distribute the wealth produced by the workers; on the other hand, to maintain a macroeconomic policy aimed at strengthening the financial capital and conservative political practices. Even worse: the use of traditional practices of corruption that destroyed the ideas of a political party that could have been different. Their policies directed at the poor ultimately further privileged consumption, with insufficient attention given to form the consciousness of the classes that live from their work. The consumer was strengthened rather than the citizen.

This context ultimately favored the reversion of a popular, although fragile project, whose option is to intensify neoliberalism, favoring international capital. An offensive by the elites and conservative forces on the right that develops constitutional reforms to justify a profound economic adjustment and the counter-reform of labor and social security laws, is historically achieved by the workers. This is a context which enhances the value of policies to restrict rights and despoil national riches, with the intensification of the overexploitation of the labor force, directing the Public Fund prior to servicing the payment of the domestic debt to support projects of interest to capital. The absolute priority is to guarantee the profit rates of capital, especially of financial capital. The poor are individualized, criminalized, and considered responsible for their situation, although this is independent from their will. In addition, freedoms are curtailed, instituting a real state of emergency under the arbitrary rule of an executive and a reactionary and corrupt legislature with the support of the media and the judiciary.

In this context, the BF has been the subject of a contradictory onslaught. On the one hand, the Temer Administration is unable to deactivate the program. Knowing its popularity and its coverage because it is present in all 5,570 Brazilian municipalities, reaching a population of more than 50 million Brazilians who live in a situation of poverty, they have been using it even as a coin to counter the criticism and lack of 
popular support for their administration ${ }^{14}$, which includes readjusting the amount paid by the benefit, as was done in July 2016, with another readjustment expected for July 2017 that was not given. On the other hand, the families that benefit from BF are seen in the current Brazilian context, basically, as dishonest and are subject to an obscure benefit review process. Thus, in March 2014, during the Dilma Administration, 14,053,368 families were helped, with funds to pay benefits in that month on the order of $\mathrm{R} \$ 2,112,724,614.00$ (U\$ 670,706,226.66) and, in July 2017 (Temer Administration), just 12,740,610 families were assisted, decreased by 2,312,778 families. The moralizing discourse is that it is necessary to clean up the program keeping only those who need it, in other words, an already conservative focus is taken further, and what is worse, it criminalizes, individualizes, and renders the poor responsible. In these terms, the BF is further away from effectively becoming an initial step to implement a Citizenship Basic Income, as already approved and sanctioned in 2004.

\section{CONCLUSIONS}

It should be considered that the change from a focused program to a universal one is a complex process, since it involves different interests and rationalities of the various subjects involved. Furthermore, focus and universalization are opposite perspectives.

When using the process of changing the $\mathrm{BF}$ to construct the Citizenship Basic Income, as determined by Law $10.835 / 2004$, enacted by the National Congress in 2003 and sanctioned by President Lula on January 8, 2004, whose implementation was to begin in 2005, several constraints should be considered to set limits to allow the desired process. To provide a basic income to all Brazilians and foreigners who have been living in Brazil for at least five years, one must consider, besides the current context in which rights are being stripped, the deactivation of social programs and the reduction of resources meant for the programs and actions that became part of a policy to deal with poverty in Brazil; several forms of constraints are: some intrinsic to the program itself, with a very low income cutoff; the requirement of conditionalities, with the widespread approval of the media and most of the segments of society; the use of a sophisticated system to follow and control the families and other constraints sustained by the dominant conservative ideology that permeates the Brazilian society and media.

Focus, as the main qualifier of the BF is founded on a liberal concept developed in the context of neoliberalism, under the theoretical reference of economic liberalism and the conservative theoretical matrix, in opposition to the universalization of rights. It depoliticizes the beneficiaries transforming them from subject into object.

It is reduced to a merely operational matter, thus merely technical, whose objective is to separate, select, and prioritize attention to the marginalized segments of the labor market. It is guided by the search for efficiency and reduces the content of the social policies of compensatory residualism. It guides the entire process of implementation of the social policies, attributing a disqualifying, reactionary character of universalization, transforming itself into an excluding and reductionist perspective. It is guided by the justice of the market, ignoring the social relations that generate poverty and wealth, centering poverty on the attributes of the individuals and their families. In this logic, it reduces the space of the State in supplying services and highlights the expansion of the market, even as a provider of services (Silva 2016b: 137, the authors' translation).

The conditionalities, another qualifying dimension of the $\mathrm{BF}$, are duly articulated to the conservative ideas regarding focus. It is the dimension of the proposal of the program that is least consensual and most contradictory, incorporated as a structuring dimension, aiming to potentiate positive impacts on the autonomization of the beneficiary families. They 
are highly approved by the media and by majority of segments of society that consider that the poor should not receive anything without giving something in exchange. This is a moralistic and conservative concept that further worsens the situation of the more vulnerable families, those with a greater propensity to non-compliance with those conditionalities (Silva, Guilhon, and Lima 2013). They ignore the precarious structural conditions of most of the Brazilian municipalities, on whom falls the greatest responsibility for the offer of services, to manage and follow up families that do not comply with conditionalities. This is a concept of conditionality based on an ideological perspective that transforms a right into a concession and as such should require a counterpart, above all if this concession is aimed at the poor who need to learn to value what they receive. It reproduces an ideology that ends by being incorporated by some of the technical people and even the beneficiaries, as found in a field study on the conditionalities and Index of Decentralized Management (IDM-Índice de Gestão Descentralizada-IGD) in the State of Maranhão (Silva et al. 2013).

A constraint that limits the transformation of the BF into the initial stage for the implementation of the Citizenship Basic Income, the use of sophisticated information systems, similarly to what happens with several income transfer programs currently being implemented in Latin America and the Caribbean should also be highlighted (Silva 2014a). Regarding this aspect, the authors emphasize the inclusion of the families in the Single Registry of the Federal Government, that maintains a database of data on the poor families; the development of the selection process of beneficiary families based on the information of the Single Registry; the management actions of social programs as regards, specifically, the process of registering the families and updating the registry, which is done every two years, and the follow up and control of the conditionalities and families that are not complying with the conditionalities $^{15}$. This reality has significantly transformed the social programs, especially as regards their management and the inclusion of new professionals, emphasizing economists and professionals in the field of informatics, contributing to raising the level of technicization of these programs, with the consequent supremacy of seeking efficiency to the detriment of efficacy and effectiveness.

Other constraints that should be highlighted result from the conservative ideology that permeates Brazilian society and media ${ }^{16}$, regarding the debate on the Basic Income that is being waged in several forums. Its main defender is the councilman of the PT in the city of São Paulo, Eduardo Suplicy. In this sense, often two unfavorable arguments are presented in the media, in the legislatures and among segments of society: (1) a very great amount of funds is needed, which is an economic argument; and (2) a universal income transfer program has a strong potential to act as an incentive against work, an ideological argument. These are arguments that counter those constructed by the defenders of the Citizenship Basic Income, such as: elimination of the excessive bureaucracy required by the focused programs; it does away with the stigma and shame that mark the beneficiaries of focused programs; it eliminates the possibility of dependence; it raises the level of liberty and dignity; it is easy to understand; and it is transparent and helps reduce inequality and eliminate poverty.

In a general appreciation on the implementation of a Citizenship Basic Income, based on the empirical approach to the reality of the income transfer in Brazil; the development of several research studies on these programs since 1995, when the first municipal experiences were implemented in Campinas/São Paulo and in Brasília/Federal District; also an empirical approach on social policies in Brazil, as well as the insertion and follow up of different moments in the juncture of Brazilian reality, the authors believe that the implementation of a Citizenship Basic Income in Brazil is still a process to be constructed and 
conquered. The authors consider that there is still a wide circulation of conservative arguments against a proposal of this nature, and among the outstanding protagonists are the media, segments of the legislative houses, and segments of Brazilian society itself. Furthermore, the authors emphasize the very nature of the $\mathrm{BF}$ as a focused program, although there has been a significant increment in the outreach of the target public: poor and extremely poor families. Moreover, the emphasis on conditionalities is a serious limitation to an unconditional Citizenship Basic Income. This is because focus, as a criterion to determine inclusion and conditionalities as obligations to be fulfilled by the families who would otherwise be subject to progressive punishments up to and including dismissal from the program if they repeat their failure to comply, is in itself a structuring element that goes against those that characterize a Basic Income, which is, by nature, unconditional. In this sense, the authors consider it unappropriate to indicate that the $\mathrm{BF}$ may be a first step in the implementation of the Citizenship Basic Income in Brazil. It would in fact be admissible to talk about transformation or extinction of the $\mathrm{BF}$ to implement an unconditional Basic Income in Brazil. This is if we wish stop using a rhetoric that appears to actually express a political strategy to delay the implementation of the Citizenship Basic Income.

The arguments presented do not attempt to express pessimism or even give up the struggle to diminish inequality and eradicate poverty in the country, but to clarify the challenges to be faced to implement the Citizenship Basic Income in the country.

\section{Acknowledgements}

This paper was presented at the 17th Congress of the Basic Income Earth Network, promoted by Basic Income Earth Network (BIEN), held in 2017, in Lisbon, Portugal.

\section{Funding}

The paper is based on a study developed with the support of
Coordination for the Improvement of Higher Education Personnel (Coordenação de Aperfeiçoamento de Pessoal de Nivel Superior-CAPES) and National Council for Scientific and Technological Development (Conselho Nacional de Desenvolvimento Científico e Tecnológico- $\mathrm{CNPq}$ ), which are Brazilian government agencies that train human resources and support research.

\section{Notes}

1. Operation Car Wash is the biggest investigation of corruption and money laundering ever performed in Brazil. It is estimated that the volume of money diverted from the coffers of Petrobrás, the biggest state-owned company in Brazil, is around billions of reais. In addition, there is the economic and political importance of the suspects of participating in the corruption scheme that involves the company. The name Car Wash is due to the use of a network of gas stations and carwashes to move illicit funds belonging to one of the criminal organizations that were initially investigated. Although the investigation has moved on to other criminal organizations, the initial name has become widely accepted (Entenda o caso: Lava jato N.d.).

2. Interview given to the Bulletin of the Job and Social Observatory (Boletim do Observatório Social e do Trabalho), year 6, no. 2.

3. The limits are as follows: I-for the financial year of 2017 , to the primary expenditures paid for in the financial year of 2016, including the remains payable and other operations that affect the result, corrected by $7.2 \%$; and II-for the later financial years, to the value of the limit referring to the immediately previous financial year, corrected by the variation of the Broad National Consumer Price Index (Índice Nacional de Preços ao Consumidor Amplo-IPCA). The base for calculation and established limits do not include: I-constitutional transfer; II-extraordinary credits; III-non-recurrent expenditures of the Electoral Courts for holding elections; and IV-expenditures due to increased capital of non-depedent state-owned companies.

4. A broad discussion and problematization about the BF is found in Silva (2016a).

5. The objective information and quantitative data presented in the characterization of the BF are found in (http://www.mds.gov.br) (Relatórios de Informações Sociais 2016).

6. Besides the $\mathrm{BF}$, among other income transfer programs that are being implemented in Brazil, the Continuing Benefit Conveyance (Beneficio de Prestação Continuada-BPC) which is non-contributive, directed at the elderly from 65 years of age upwards and to people with a handicap who 
cannot work, and live in families with a family per capita income less than $1 / 4$ of the minimum wage; Rural Social Security, which is a special retirement regime which does not require prior systematic contributions, and is directed at people who work in family farming. Both programs transfer a monthly monetary benefit of one minimum wage to the beneficiaries (R\$ 937.00 in 2017, approximately U\$ 297.46).

7. The Single Registry is a system to register information about Brazilian families with a per capita family income of up to half of a minimum wage, and is a database used by the social programs of the Federal Government.

8. The dollar was calculated according to the day's quotation (July 18, 2017) when one dollar was equivalent to R\$ 3.15 (https://economia.uol.com.br/cotacoes/cambio/dolar-comer cial-estados-unidos/).

9. The process of increasing the number of families in the program was interrupted in May 2016, when Michel Temer became President of Brazil after the impeachment of President Dilma Rousseff. This is the central topic of the present text.

10. The person preferentially responsible for the $\mathrm{BF}$, in the family, is the mother, or woman responsible for the family, and they are over $80 \%$ of the legal representatives.

11. The nominal values of the monetary benefits of the BF were only updated in 2007, 2008, 2009, 2011, and 2016, with a new readjustment expected in July 2017.

12. Brazil without Extreme Poverty Plan, created in 2011, was aimed at the 16.2 million Brazilians who lived with a monthly per capita income lower than the extreme poverty line (R\$70.00, U\$ 22.22), based on three program areas: (1) Guaranteed Income, incorporating the $\mathrm{BF}$, as the main program; Rural Social Security; Continued Benefit; and emergency income transfer programs: Green Grant (Bolsa Verde), Drought Grant (Bolsa Estiagem), and others; (2) Productive Inclusion: National Program to Strengthen Family Farming (Programa Nacional de Fortalecimento da Agricultura Familiar-PRONAF); Urban and rural microcredit: Friendly Credit from Banco do Nordeste (Crédito Amigo do Banco do Nordeste); Growth Program (Programa Crescer) of the Federal Government; incentive to entrepreneuralism and incentive to solidarity economy; Professional Qualification: National Program for Access to Technical Education and Jobs (Programa Nacional de Acesso ao Ensino Técnico e Emprego-PRONATEC) to qualify the poorest segments; and (3) Access to public services: water (water for all), light (light for all), health (Strategy of Family Health, Smiling Brazil, offer of medications), education (Literate Brazil, Program More Education-complete education), housing (My Home, My Life, My Better Home), and Food (popular restaurants, school lunch).

13. The pre-salt is an area of oil reserves discovered in 2006 under a thick layer of saline rock that is one of the several rock layers of the marine sub-soil.

14. The popularity of the Temer Administration is the lowest in history. In June 2017, it reached an approval of only 3\% of the Brazilian population.

15. About focusing and the conditionaities of BF, see Silva (2016a).

16. A discussion on the limits of BF considered the initial step to the implementation of the Citizenship Basic Income in Brazil is already being problematized by Maria Ozanira da Silva in papers presented at the 14th and 15th BIEN (Silva 2012; 2014b).

\section{References}

Barros, R. P. de, M. de Carvalho, S. Franco, and R. Mendonça. 2009. "Determinantes da queda da desigualdade de renda no Brasil" (Fall and Inequality Determinants of Income in Brazil). In Situação social brasileira: 2007 (Brazilian Social Situation: 2007), edited by J. A. de Castro and J. A. C. Ribeiro. Brasília, DF: IPEA.

Beneficios (Benefits). 2015. Brasília, DF: MDS. Retrieved (http://www.mds.gov.br).

Carvalho, A. M. P. de. 2017. A Proteção Social na Atual Conjuntura Brasileira: A Politica de Assistência Social nos circuitos do desmonte da seguridade brasileira (The Social Protection in the Brazilian Conjuncture: The Aid Policy in the Dismounting of the Brazilian Security). Fortaleza: Mimeo.

Entenda o caso: Lava jato (Understand the Operation Car Wash). N.d. Brasília, DF: MPF. Retrieved (http://lavajato. mpf.mp.br/entenda-o-caso).

Holanda, F. M. de and V. Anchieta Junior. 2014. "Prontos para a mudança de ciclo? O que mostram os dados desagregados recentes do mercado de trabalho brasileiro" (Ready to Change the Cycle? What Is Pointed out by Recent Data of the Brazilian Job Market). Boletim do Observatório Social $e$ do Trabalho (Bulletin of Social and Job Observatory) 3(2):1-4.

Instituto Brasileiro de Geografia e Estatística (IBGE). 2011. Censo Demográfico 2010 (Demographic Census 2010). Rio de Janeiro.

- 2013. Pesquisa Mensal de Emprego (Job Monthly Research). Brasília, DF. Retrieved (http://www.ibge.gov.br/ home/estatistica/indicadores/trabalhoerendimento/pme_nov a/).

. 2015a. Pesquisa Mensal de Emprego (Job Monthly Research). Brasília, DF. Retrieved (http://www.ibge.gov.br/ home/estatistica/indicadores/trabalhoerendimento/pme_nov a/). 
—. 2015b. Pesquisa Nacional por Amostra de Domicílios Contínua (Continuous National Household Sample Survey). Rio de Janeiro. Retrieved (http://www.ibge.gov.br/home/ estatistica/indicadores/trabalhoerendimento/pnad_continua/ default_tabelas_uf.shtm).

- 2016. Pesquisa Nacional por Amostra de Domicílios Contínua: Tabelas por unidade de federação (Continuous National Household Sample Survey: Tables by Federation Unit). Rio de Janeiro. Retrieved (http://www.ibge.gov.br/ home/estatistica/indicadores/trabalhoerendimento/pnad_con tinua/default_tabelas_uf.shtm).

Instituto de Pesquisa Econômica Aplicada (IPEA). 2010. "Previdência e assistência social: Efeitos no rendimento familiar e sua dimensão nos Estado" (Social Security and Social Aid: Effects on Family Income and Its Dimension in the States). Comunicado do Presidente (President Communication) 5(58):25-37. Retrieved (http//:www.ipea. gov.br).

—. 2016. Políticas sociais: Acompanhamento e análise (Social Policies: Following and Analysis) 6(24):25-37. Retrieved (http://www.ipea.gov.br/portal/images/stories/ PDFs/politicas_sociais/20170519_bps24.pdf).

Instituto Maranhense de Estudos Socioeconômicos e Cartográficos (IMESC). 2017. Boletim de Conjuntura Econômica Maranhense (Maranhão State Economic Conjuncture Bulletin). Retrieved (http://www.imesc.ma.gov. br/).

Lima, V. F. S. de A., G. B. P. Moraes, and R. T. C. Silva. 2017. "A atual conjuntura de aprofundamento da precarização do trabalho no Brasil no Maranhão e as recentes medidas de flexibilização das relações de trabalho" (The Actual Conjuncture of Deepening of Job precariousness in Brazil and in Maranhão State and the Recent Rules of Flexibilization in the Job Relations). Boletim do Observatório Social e do Trabalho (Bulletin of Social and Job Observatory) 6(2):1-6.

Lima, V. F. S. de A., T. de S. Nascimento, and J. S. de A. Mochel. 2009. "Informalidade das relações de trabalho no Brasil: Determinações de novas configurações" (Informality of Job Relations in Brazil: Determinations of the New Configurations). Presentd at 4th Jornada Internacional de Políticas Públicas (JOINP), 2009, PPGPP/UFMA, São Luís.

Lima, V. F. S. de A., V. Anchieta Junior, and R. M. de Sousa. 2015. "Rebatimentos da recessão no mercado de trabalho e mudanças regressivas no marco regulatório" (Repercussion of the Recession in the Job Market and Regressive Changes in the Regulatory Market). Boletim do Observatório Social e do Trabalho (Bulletin of Social and Job Observatory) 4(3):1-4.

Pochmann, M. 2017. "Crise, mercado de trabalho e mudanças na regulação pública do trabalho no Brasil” (Crisis, Job Market and Changes in the Public Regulation in Job in Brazil). Boletim do Observatório Social e do Trabalho (Bulletin of Social and Job Observatory) 6(2):1-3.

Ramos, L. and R. Cavaleri. 2009. "O mercado de trabalho brasileiro em 2007" (The Brazilian Job Maket in 2007). In Situação social brasileira: 2007 (Brazilian Social Situation: 2007), edited by J. A. de Castro and J. A. C. Ribeiro. Brasília, DF: IPEA.

Relatórios de Informações Sociais (Social Data Report). 2016. Brasília, DF: MDS. Retrieved (https://aplicacoes.mds.gov. br/sagi/RIv3/geral/index.php).

Silva, M. O. da S. e. 2012. "The Bolsa Família and the Social Protection in Brazil: Problematizing the Conditionalities as Limits for Implementation of the Citizenship Basic Income." Presentd at 14th Congress of the Basic Income Earth Network, 2012, BIEN, Minich, Germany.

_.2014a. Programas de Transferência de Renda na América Latina e Caribe (Income Transfer Programs in Latin America and Carib). São Paulo: Cortez Editora.

—. 2014b. "The Conditionalities of the Bolsa Família: Its Conservative Face and Limitations to Implement the Citizenship Basic Income in Brazil." Prsented at 15th Congress of the Basic Income Earth Network, 2014, BIEN, Montreal.

- 2016a. O Bolsa Familia: Verso e reverso (The Family Stipend: Verse and Reverse). Campinas: Papel Social.

— 2016b. O Mito e a Realidade no Enfrentamento à Pobreza na América Latina: Estudo comparado de Programas de Transferência de Renda no Brasil, Argentina e Uruguai (The Myth and Reality in Facing Poverty in Latin America: Compared Study of the Income Transfer Programs in Brazil, Argentina and Uruguay). São Paulo: Cortez Editora.

Silva, M. O. da S. e., M. C. Yazbek, and G. Di Giovanni. 2014. A Política Social no Século XXI: Prevalência dos Programas de Transferência de Renda (The Social Policy in XXI Century: Prevalence of Income Transfer Programs). 5th ed. São Paulo: Cortez Editora.

Silva, M. O. da S. e., M. V. M. Guilhon, and V. F. S. de A. Lima. 2013. "As Condicionalidades e o Índice de Gestão Descentralizada (IGD) enquanto Dimensões Centrais do Bolsa Família (BF): Uma incursão na realidade do programa no Maranhão" (The Conditionalities and the Decentralized Administration Index as Central Dimensions of the Family Stipend: An Incursion in the Reality of the Program in Maranhão State). Cadernos de Pesquisa (Research Report) 1(1):35. Retrieved (http://www.gaepp. ufma.br). 


\section{Bios}

Maria Ozanira da Silva e Silva, Ph.D. in Social Work, professor of the Graduate Program in Public Policies (Programa de Pós-Graduação em Políticas Públicas) at Federal University of Maranhão State (Universidade Federal do Maranhão - UFMA), São Luís, MA, Brazil, coordinator of the Group for the Evaluation and Study of Poverty and Policies Focused on Poverty (GAEPP—Grupo de Avaliação e Estudo da Pobreza e de Politicas direcionadas à Pobreza, http://www.gaepp.ufma.br), researcher level 1 of the National Council for Scientific and Technological Development
(Conselho Nacional de Desenvolvimento Cientifico $e$ Tecnológico- $\mathrm{CNPq}$ ), Brazilian government agency that finances the development of researches; research fields: social policies, evaluation of social policies and social programs.

Valéria Ferreira Santos de Almada Lima, Ph.D. in Public Polices, professor and coordinator of the Graduate Program in Public Policies (Programa de Pós-Graduação em Políticas Públicas) at Federal University of Maranhão State (Universidade Federal do Maranhão-UFMA), São Luís, MA, Brazil, researcher of the GAEPP, researcher of the CNPq, level 2; research fields: job and income policies, evaluation of social policies and social programs. 